\title{
Study on the Anchorage Location Selection of the New Method
}

\author{
Xiao-Dong LIU ${ }^{1, a}$, Li MING ${ }^{1, b,}$, Hai-Lan SUN ${ }^{2, c}$ \\ ${ }^{1}$ School of Navigation, Wuhan University of Technology, Wuhan, 430063 China \\ ${ }^{2}$ School of City Construction, Jiangxi Normal University, Nanchang, 330027 China \\ axdwq1206@126.com, blimingt12@163.com, csunhailan@yeah.net
}

${ }^{*}$ Corresponding author

\begin{abstract}
Keywords: The Yangtze River, Anchorage Location Selection, Multi-objective Optimization, Comprehensive Evaluation Model.
\end{abstract}

\begin{abstract}
Anchorage location selection is one of important factors concerning the safety of vessel in the Yangtze river. On the basis of the characteristics of the inland ports and channels, this paper fully considers the safety of anchoring vessels, the surrounding facilities and the vessels sailing nearby, refines the influence factors of anchorage location selection in the Yangtze river, analyses the influence factors individually, evaluates comprehensively influence factors of the Yangtze river anchorage location selection by using the multi-objective optimization method, constructs the Yangtze river anchorage location selection comprehensive evaluation model, and gives an example of anchorage location selection in Ezhou port as application instance. The establishment of the model enriches the theory related to inland river anchorage, provides theoretical guidance for the Yangtze river anchorage location selection.
\end{abstract}

\section{Introduction}

Anchorage is water area used for vessels to temporarily berth such as waiting for berthing, joint inspection, taking shelter from the wind. For inland port, the anchorage is a very important resource. It has become the center of the port for vessels entering or leaving the port to gather, and it is an important link in the whole process of port operation and management. The inland river anchorage often coexists with inland channel in the river, so the anchorage location selection is one of the important factors related to the inland shipping safety; With the development of shipping in the Yangtze river, there are more and more vessels navigating on the Yangtze river, and more and more demands for anchorage berth, but there is less and less water room for anchoring, therefore it is important to study on anchorage location selection.

There is little research on anchorage in the river. Huang, et al. (2011) focuses on improving the utilization rate of the inland river anchorage,Jovanović et al. (2005) focuses on anchorage capacity required in an inland port. The research on anchorage location selection is much less, and most of it focuses on the study of seaport anchorage location selection. Hu and Zhang (2005) selected seven influencing factors such as the water depth, bottom sediment, topography, room for manoeuvre, shelter conditions, tidal current, and the distance to terminal, studied on anchorage location selection in Ningbo port using the analytic hierarchy process; Chen (2007) selected some influencing factors such as the bottom sediment, water depth, wind, sea current, distance between anchorage and channel, studied on anchorage location selection in Caofeidian port. Because the characteristics of inland ports and fairway is different from that of seaports and route, the requirements of anchorage location selection in inland river is very different from that in seaport. The current practice is that anchorage location is selected in inland river according to Design specification of harbor engineering (2007). In this standard, there are some provisions on the influence factors of anchorage location such as bottom sediment, water depth, current, wind and waves, but the influence factors are not enough complete and comprehensive and all of them are qualitative. It is not convenient to guide the actual work. Bian, et al. (2007) focused on the layout and site selection of inland river-way service center, constructed a multi-objective optimization evaluation index system, set up service center layout and site selection optimization mathematical model based on neural network, it has a certain reference significance to the anchorage location selection.

This paper comprehensively analyzes the influence factors of the Yangtze River anchorage location selection, evaluates comprehensively influence factors of the Yangtze River anchorage location selection 
by using the multi-objective optimization method, constructs the Yangtze river anchorage location selection comprehensive evaluation model. The establishment of the model enriches the theory related to inland river anchorage, provides theoretical guidance for the Yangtze river anchorage location selection.

\section{Analysis of Anchorage Location Selection Influence Factors}

Anchorage location selection in inland river is a very complex work, there are many influence factors to be considered. Some of the influence factors must meet the basic requirements for anchorage location selection, such as the distance between anchorage and the hydraulic structures, water depth. If these factors cannot meet the basic requirements, the location of the anchorage should not be selected here, and when these factors meet the basic requirements, the value of these factors has little influence on the anchorage location selection, so these factors were called as mutational influence factors. While other factors such as the distance between anchorage and the terminal, wind and wave, etc., its influence on the anchorage location selection will change along with the change of its value, so these factors were called as gradual change influence factors.

\section{Mutational Influence Factors}

The Distance between Anchorage and the Hydraulic Structures. There are many hydraulic structures such as bridges, aqueduct and underwater pipeline. When vessels are anchoring near the hydraulic structures, there is possible for vessels to cause harm to the hydraulic structures, so the distance between anchorage and the hydraulic structures should be considered when anchorage location is selected.

Stipulated in Design specification of harbor engineering: the safe distance between anchorage and bridge, aqueduct should not be less than the provisions of the table 1 .

Tab. 1 The Safe Distance between Anchorage and Bridge, Aqueduct(m)

\begin{tabular}{|c|c|c|}
\hline $\begin{array}{c}\text { type of hydraulic } \\
\text { structure }\end{array}$ & $\begin{array}{c}\text { Anchorage in upstream } \\
\text { waters }\end{array}$ & $\begin{array}{c}\text { Anchorage in downstream } \\
\text { waters }\end{array}$ \\
\hline bridge & $4 \mathrm{~L}$ & $2 \mathrm{~L}$ \\
\hline aqueduct & & \\
\hline
\end{tabular}

Note: $\mathrm{L}$ stand for the length of the designed vessel type to the terminal nearby.

According to the provisions of the people's Republic of China Petroleum and natural gas pipeline protection law, anchoring is prohibited for vessels within five hundred meters on both sides of the center line of the pipeline which crosses the channel, so anchorage should not be set up within five hundred meters on both sides of the center line of the petroleum and natural gas pipeline which crosses the channel.

Water Depth in Anchorage. The location that the water depth is larger in inland river is usually chosen for fairway, and the anchorage is in the sides of the fairway, but the proper water depth is the basic condition for an anchorage. Its water depth should ensure the anchoring vessels in the anchorage have no risk of grounding, so water depth is an important factor to be considered for anchorage location selection.

Water depth(D) in the anchorage should be more than the sum of the following elements: the maximum designed draft of the vessel $\left(D_{d}\right)$, minimum under keel clearance $\left(D_{s}\right)$, spare depth for wave $\left(D_{w}\right)$, spare depth for siltation $\left(D_{m}\right)$, sounding error $\operatorname{limit}\left(D_{e}\right)$ and draft increment caused by $\operatorname{trim}\left(D_{t}\right)$ and $\operatorname{list}\left(D_{1}\right)$.

$D_{d}$ is maximum designed draft for the designed vessel type to the terminal nearby. $D_{s}$ is determined according to table 2 .

Tab. 2 Minimum under Keel Clearance(m)

\begin{tabular}{|l|c|c|c|c|}
\hline \multicolumn{2}{|l|}{ DWT of designed vessel type } & $100 \leq$ DWT $<500$ & $500 \leq$ DWT $\leq 3000$ & DWT $>3000$ \\
\hline \multirow{2}{*}{$\begin{array}{l}\text { bottom } \\
\text { sediment }\end{array}$} & mud & 0.20 & 0.30 & 0.50 \\
\cline { 2 - 5 } & rock & 0.30 & 0.50 & 070 \\
\hline
\end{tabular}

Note: DWT stand for Deadweight Tonnage. 
$D_{w}$ is spare depth for sinking because of wave. It is calculated according to half wave height. $D_{m}$ is determined according to back-silting strength, maintenance dredging interval and characteristic of dredging plant. Its value is not less than $0.2 \mathrm{~m} . \mathrm{D}_{\mathrm{e}}$ is $0.2 \mathrm{~m}$ when the water depth is less than or equal to $20 \mathrm{~m}$ and it is ten percent of depth value when the water depth is more than $20 \mathrm{~m}$. $\mathrm{D}_{\mathrm{t}}$ is related to the load and size of vessel. The trim of a full loaded large vessel is required to be zero normally before arrival at port. And the trim of a full loaded vessel which DWT is about 10,000 tons is required to be $0.3-0.5 \mathrm{~m}$ normally, which means that $D_{t}$ is about $0.2 \mathrm{~m}$. $D_{t}$ of smaller vessels in upper middle reach of the Yangtze river is about $0.1 \mathrm{~m}$.

The maneuver of the vessel regulates the vessel to be even keel when the vessel is listing. But when regulating, there will be some deviation. The minimum scale of indicating equipment is $1^{\circ}$, so that the error limit is $0.5^{\circ}$ when regulating. The formula below is used to calculate $\mathrm{D}_{1}$.

$$
D_{1}=\frac{0.5 B}{2 \times 57.3}
$$

Here : B stand for vessel breadth(m).

Valid Width of Waters. Valid width of waters refers to the width of the water in which water depth is greater than the minimum requirements of anchorage water depth. In inland waters, anchorage and fairway coexist. The enough width of the fairway must be ensured firstly, and then the extra water room could be considered to set up anchorage. Anchorage area must have certain width to meet the requirements of vessel's mooring. Apart from the width of fairway, the remaining water includes two parts at least. One part is the distance between anchorage and fairway nearby, and another part is the width of anchorage area.

If the distance between anchorage and fairway nearby is too small, it will affect the safety of vessels sailing in the fairway. But overlarge distance is wasteful. The distance between anchorage and fairway nearby should be not less than $20 \mathrm{~m}$ in consideration of that the vessel in the fairway should keep clear of lateral marks. The width of anchorage area should meet the requirement for a column of vessels anchoring.

The Distance between Anchorage and Obstacles, Shoals Nearby. In order to avoid that dragging anchor vessels in anchorage collide the obstacles nearby such as reefs, wrecks or ground, the direction in line of anchorage and obstacles nearby, shoals should be not in keeping with the direction of the main current and strong wind when choosing the location of anchorage. Otherwise, the relative distance should be greater than the value of multiplying the time of emergency stand by engine by the drifting velocity of the vessel.

The Distance between Anchorage and Branching Estuaries, Eddy Current Area. There are many tributaries along the Yangtze river. When an anchorage is located in or near branching estuary, it is difficult for vessels to get in and out of the tributary rivers, especially when there are vessels encounter near the branching estuary, so it is obviously improper that an anchorage is set up in or near branching estuaries. It is difficult for vessels to manoeuvre in eddy current area. When an anchorage is located in eddy current area, it is dangerous for vessels to get in and out of the anchorage or manoeuvre in anchorage area. Therefore, it should be avoided that an anchorage is set up in the eddy current area.

For the similar reason with the distance between anchorage and the hydraulic structures, the minimum distance between anchorage area and the branch estuary, eddy current area should be 4L when the anchorage is in upstream waters and $2 \mathrm{~L}$ when the anchorage is in downstream waters.

\section{Gradual Change Influence Factors}

Bottom Sediment and Topography. The bottom sediment and topography have big influence on anchor holding power, and the anchor holding power is the key to ensure anchoring vessels not to drag anchor, so the bottom sediment and topography is an important factor to be considered for anchorage location selection.

The sand bottom with fit hardness and clay bottom are better for anchoring. The mixture of sand and mud take second place. Hard sand and mud is worse. The rock bottom are not fit for anchoring. Moreover, even ground in anchorage is better. Steep gradient will weaken the holding power of anchor so that 
dragging anchor happens.

Current Condition. The river current in anchorage has big influence on the safety of anchoring vessels, and large current is easy to cause anchoring vessels to drag anchor. So the current condition is a main factor to be considered for anchorage location selection.

The Condition of Wind and Wave. In the Yangtze river, the wind and waves are relatively weak, but sometimes they are strong in the lower reaches of the Yangtze river, especially in the summer when a typhoon invades, so the wind and wave condition is one of the factors to be considered for anchorage location selection.

The Degree of River Bend. In general, it is difficult for vessels to sail in a bend. When an anchorage is located in a bend, it is adverse for passing vessels to keep clear the anchoring vessels. Therefore, an anchorage location should be as far as possible set up in straight channel.

The degree of river bend is related to radius of curvature. When radius of curvature is $20 \mathrm{~L}$, the turning angle that the vessel passes $1 \mathrm{~L}$ range is one-twentieth radian $\left(2.9^{\circ} \mathrm{C}\right.$ or so), whose influence is little.

The Distance between Anchorage and the Terminal. Anchorage should be as far as possible set up near the terminal. If the anchorage is far away from the terminal, it is inconvenient for vessels to get alongside the terminal. Therefore, the distance between anchorage and the terminal is one of the factors to be considered for anchorage location selection.

\section{The Model and Instance of Anchorage Location Selection}

\section{Model Constructing}

For constructing the model of anchorage location selection, every factor is valuated. $\mathrm{F}_{1} \sim \mathrm{F}_{10}$ are respectively used to express the influence value of the 10 factors, that is, the distance between anchorage and the hydraulic structures, water depth in anchorage, valid width of waters, the distance between anchorage and obstacles, shoals nearby, the distance between anchorage and branching estuaries, eddy current area, bottom sediment and topography, current condition, the condition of wind and wave, the degree of river bend, the distance between anchorage and the terminal.If a mutational influence factor meet the basic requirement, its influence value is assigned to 1 . Otherwise, it is 0 . The influence value of gradient influence factors is assigned according to table 3.

Tab.3 The Influence Value of Gradient Influence Factors

\begin{tabular}{|c|c|c|c|c|}
\hline value & 1 & 2 & 4 & 10 \\
\hline factor & $\begin{array}{c}\text { sand with fit } \\
\text { hardness or clay }\end{array}$ & $\begin{array}{c}\text { mixture of sand } \\
\text { and mud }\end{array}$ & $\begin{array}{c}\text { hard sand or } \\
\text { soft mud }\end{array}$ & $\begin{array}{c}\text { rock or } \\
\text { heavy silt }\end{array}$ \\
\hline topography gradient & $0^{\circ} \sim 5^{\circ}$ & $6^{\circ} \sim 10^{\circ}$ & $11^{\circ} \sim 15^{\circ}$ & $\geq 16^{\circ}$ \\
\hline mean velocity of current & $0 \sim 1 \mathrm{~m} / \mathrm{s}$ & $1 \sim 2 \mathrm{~m} / \mathrm{s}$ & $2 \sim 3 \mathrm{~m} / \mathrm{s}$ & $>3 \mathrm{~m} / \mathrm{s}$ \\
\hline mean wind speed & $0 \sim 1.5 \mathrm{~m} / \mathrm{s}$ & $1.6 \sim 5.4 \mathrm{~m} / \mathrm{s}$ & $5.5 \sim 10.7 \mathrm{~m} / \mathrm{s}$ & $\geq 10.8 \mathrm{~m} / \mathrm{s}$ \\
\hline Mean height of wave & $0 \sim 0.5 \mathrm{~m}$ & $0.5 \sim 1.25 \mathrm{~m}$ & $1.25 \sim 2.5 \mathrm{~m}$ & $>2.5 \mathrm{~m}$ \\
\hline $\begin{array}{c}\text { radius of curvature of river } \\
\text { bend }\end{array}$ & $>20 \mathrm{~L}$ & $15 \mathrm{~L} \sim 20 \mathrm{~L}$ & $10 \mathrm{~L} \sim 15 \mathrm{~L}$ & $<10 \mathrm{~L}$ \\
\hline $\begin{array}{c}\text { the distance between } \\
\text { anchorage and the terminal }\end{array}$ & $<2 \mathrm{~km}$ & $2 \sim 5 \mathrm{~km}$ & $5 \sim 10 \mathrm{~km}$ & $>10 \mathrm{~km}$ \\
\hline
\end{tabular}

In table $3, F_{6}$ is equal to the sum of the value of bottom sediment and topography gradient, while $F_{8}$ is equal to the sum of the value of mean wind speed and mean height of wave.

$F$ is used to express the influence value of all influence factors, and it can be calculated according to the formula below.

$\mathrm{F}=\mathrm{F} 1 \times \mathrm{F} 2 \times \mathrm{F} 3 \times \mathrm{F} 4 \times \mathrm{F} 5 \times(\mathrm{F} 6+\mathrm{F} 7+\mathrm{F} 8+\mathrm{F} 9+\mathrm{F} 10)$

When $\mathrm{F}=0$ or $\mathrm{F}>15$, it is unsuitable to set up anchorage. Beyond that, the smaller the value of $\mathrm{F}$ is, the 
more suitable for setting up anchorage.

\section{The Instance}

Ezhou port is located at about $943 \mathrm{~km}$ downstream mileage of the Yangtze river. Appropriate water area is to be looked for to set up anchorage within the scope of every $10 \mathrm{~km}$ upstream and downstream reach of Ezhou port. Because the water depth and other hydrological data of the Yangtze river vary widely in the drought period, medium water period and flood period, anchorage location selection should be conducted respectively. It assumed that the Yangtze river is in medium water period, and the water level of Ezhou port is $5.10 \mathrm{~m}$.

According to the statistical material of Ezhou port, the length of the biggest designed vessel type is $110 \mathrm{~m}$, the breadth is $19.2 \mathrm{~m}$ and the draft is $4.3 \mathrm{~m}$. DWT is $5000 \mathrm{t}$.

Inspection of Mutational Influence Factors.There are Ehuang bridge and Bahe branch within the above-mentioned scope of water area. According to the basic requirements of the mutational influence factors, the water area between $440 \mathrm{~m}$ upper stream and $220 \mathrm{~m}$ lower stream of the Ehuang bridge and the water area between $440 \mathrm{~m}$ upper stream and $220 \mathrm{~m}$ lower stream of the Bahe branch estuary are not appropriate to set up anchorage.

Bottom sediment in Ezhou port is mixture of sand and mud. $\mathrm{D}_{\mathrm{s}}$ is $0.5 \mathrm{~m}$. The height of wave in Ezhou port is $0.4 \mathrm{~m}$. $\mathrm{D}_{\mathrm{w}}$ is $0.2 \mathrm{~m}$. Calculated according to formula (1), $\mathrm{D}_{1}$ is $0.08 \mathrm{~m}$.

$\mathrm{D}=\mathrm{D}_{\mathrm{d}}+\mathrm{D}_{\mathrm{s}}+\mathrm{D}_{\mathrm{w}}+\mathrm{D}_{\mathrm{m}}+\mathrm{D}_{\mathrm{e}}+\mathrm{D}_{\mathrm{t}}+\mathrm{D}_{\mathrm{l}}=4.3+0.5+0.2+0.2+0.2+0.1+0.08=5.58 \mathrm{~m}$

The water depth in anchorage should be more than $5.58 \mathrm{~m}$. Because actual depth at a given time and place is equal to the sum of the water level at a given time and place and depth shown on the figure, the water area that its depth shown on the figure is less than $0.48 \mathrm{~m}(5.58-5.10=0.48 \mathrm{~m})$ is regarded as a shallow area or shoal.

There are 4 water areas in which the water depth and valid width of water meets the basic requirement, as shown in the figure 1 and figure 2 .

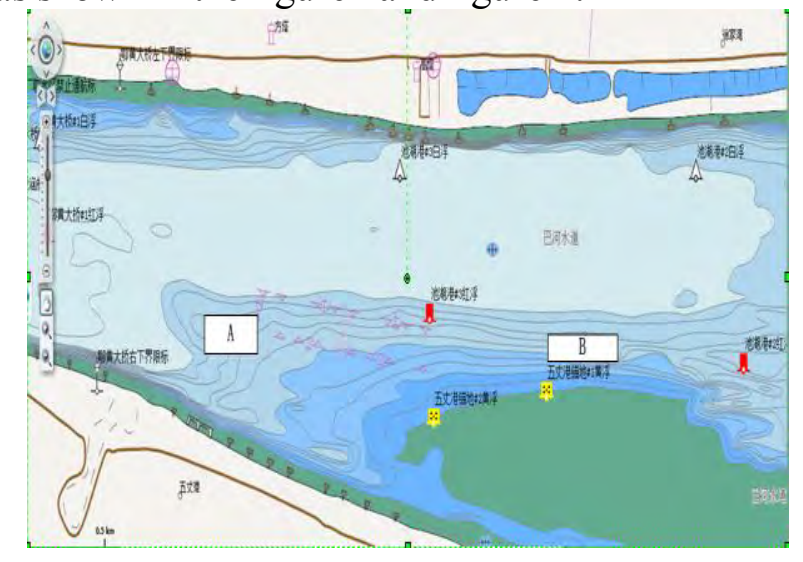

Fig. 1 Channel near the Ezhou Port(1)

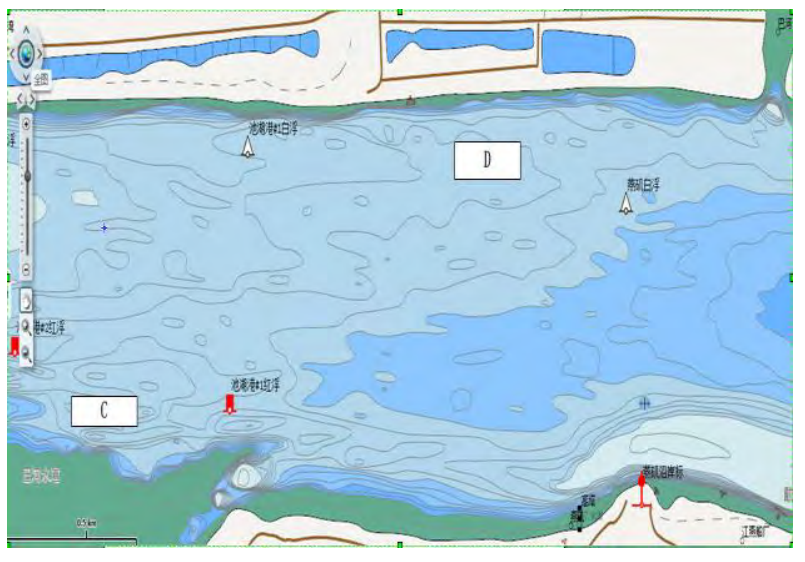

Fig. 2 Channel near the Ezhou Port(2)

There is a shoal in downstream area of the water area A. When anchorage is set up in water area $\mathrm{A}$, the distance between anchorage and the shoal must be enough. In general, it takes the vessel 30 minutes to stand by engine. The drifting velocity of a dragging anchor vessel is decided by the current. The current in water area $A$ is $1.2 \mathrm{~m} / \mathrm{s}$,so the distance between anchorage and the shoal should be more than $2160 \mathrm{~m}$.

There is a shoal on the south of the water area B. But the direction of the current in water area B is east, so that anchorage location is chosen in water area $\mathrm{B}$ is possible. There is a shoal in downstream area of the water area $\mathrm{C}$ too. The current in water area $\mathrm{C}$ is $0.82 \mathrm{~m} / \mathrm{s}$, so the distance between anchorage and the shoal should be more than $1476 \mathrm{~m}$. There is no enough water room for anchorage in water area $\mathrm{C}$. There is no shoal or obstacle near the water area D.

Value Assignment of Influence Value of Gradual Change Influence Factors. It is possible to set up anchorage in water area A, B and D. the information of gradual change influence factors is shown in table 4 , and the influence value of gradual change influence factors of water area A, B and D is assigned, as shown in table 5. 
Tab. 4 Information of Gradual Change Influence Factors

\begin{tabular}{|c|c|c|c|c|c|c|c|}
\hline $\begin{array}{c}\text { Water } \\
\text { area }\end{array}$ & $\begin{array}{c}\text { bottom } \\
\text { sediment }\end{array}$ & $\begin{array}{c}\text { topography } \\
\text { gradient }\end{array}$ & $\begin{array}{c}\text { mean } \\
\text { velocity } \\
\text { of current }\end{array}$ & $\begin{array}{c}\text { mean } \\
\text { wind } \\
\text { speed }\end{array}$ & $\begin{array}{c}\text { Mean } \\
\text { height } \\
\text { of wave }\end{array}$ & $\begin{array}{c}\text { radius of } \\
\text { curvature of } \\
\text { river bend }\end{array}$ & $\begin{array}{c}\text { the distance } \\
\text { between } \\
\text { anchorage and } \\
\text { the terminal }\end{array}$ \\
\hline $\mathrm{A}$ & $\begin{array}{c}\text { mixture of } \\
\text { sand and } \\
\text { mud }\end{array}$ & $0.001^{\circ}$ & $1.2 \mathrm{~m} / \mathrm{s}$ & $\begin{array}{c}2.6 \\
\mathrm{~m} / \mathrm{s}\end{array}$ & $0.4 \mathrm{~m}$ & $>20 \mathrm{~L}$ & $<2 \mathrm{~km}$ \\
\hline $\mathrm{B}$ & $\begin{array}{c}\text { mixture of } \\
\text { sand and } \\
\text { mud }\end{array}$ & $0.001^{\circ}$ & $1.5 \mathrm{~m} / \mathrm{s}$ & $\begin{array}{c}2.7 \\
\mathrm{~m} / \mathrm{s}\end{array}$ & $0.3 \mathrm{~m}$ & $>20 \mathrm{~L}$ & $2.45 \mathrm{~km}$ \\
\hline $\mathrm{D}$ & $\begin{array}{c}\text { mixture of } \\
\text { sand and } \\
\text { mud }\end{array}$ & $0.001^{\circ}$ & $0.71 \mathrm{~m} / \mathrm{s}$ & $\begin{array}{c}2.3 \\
\mathrm{~m} / \mathrm{s}\end{array}$ & $0.3 \mathrm{~m}$ & $>20 \mathrm{~L}$ & $6.6 \mathrm{~km}$ \\
\hline
\end{tabular}

Tab. 5 Value Assignment of Influence Value of Gradual Change Influence Factors

\begin{tabular}{|c|c|c|c|c|c|c|c|c|}
\hline Water area & \multicolumn{2}{|c|}{$\mathrm{F}_{6}$} & $\mathrm{~F}_{7}$ & \multicolumn{2}{|c|}{$\mathrm{F}_{8}$} & $\mathrm{~F}_{9}$ & $\mathrm{~F}_{10}$ & $\mathrm{~F}$ \\
\hline $\mathrm{A}$ & 2 & 1 & 2 & 2 & 1 & 1 & 1 & 10 \\
\hline $\mathrm{B}$ & 2 & 1 & 2 & 2 & 1 & 1 & 2 & 11 \\
\hline $\mathrm{D}$ & 2 & 1 & 1 & 2 & 1 & 1 & 4 & 12 \\
\hline
\end{tabular}

It is suitable to set up anchorage in water area $\mathrm{A}, \mathrm{B}$ and $\mathrm{D}$, but the most suitable location for Ezhou port anchorage is in water area A.

\section{Conclusion}

By value assignment to influence factors of anchorage location selection, this paper has carried on a quantitative research on anchorage location selection in the Yangtze river. It is a new attempt, but the rationality of the value of various influence factors remains to be further research.

\section{References}

[1]Bian, H., Xiao S. and Yin Z.J. Inland River- way Service Centre Layout and Site Selection Method. Port and Waterway Engineering, 2,2007, pp. 6-10.

[2]Chen S.Q. The Research on the Reasonable Layout and Optimal Design of Port Anchorage. Master's Thesis, Dalian Maritime University,2007, China.

[3]Huang, S.Y., Hsu, W.J. and He, Y.X. Assessing capacity and improving utilization of anchorages. Transportation Research Part E, 47(2011), pp. 216-227.

[4]Hu, Y.P. and Zhang, C.H. Application of AHP in the Selection of Ningbo Port's Anchorage. navigation of china,3(2005), pp.15-18.

[5]Jovanović, S., Olivella, J. and Radmilović, Z. Ship waiting time in a river port with priority servicing and limited anchorage area. Maritime Heritage and Modern Ports, 79(2005), pp. 301-309.

[6]The Ministry of Communications of the People's Republic of China. (2007) Industrial Standard of the People's Republic of China: Design specification of harbor engineering. China Communications Press, Beijing(2007). 